\section{School health, nutrition and education for all: levelling the playing field}

Authors: MCH Jukes, LJ Drake \& DAP Bundy Publisher: CABI Publishing, Wallingford, 2007 ISBN-13: 978-1-845-93311-1; paperback; 160 pages; price £29.95

This clearly structured textbook provides a good outline on the effectiveness of health and nutrition programmes in improving education and equity. The authors guide their reader carefully through the seven chapters providing evidence to build the argument for promoting school health, nutrition and education for all.

Pivotal to their line of thought, the authors give the readers a view from different angles exploring the interactions between education, nutrition and health. While these different views add to the comprehensiveness they come at the expense of some repetition. The reader, however, can skip a section without losing the thread and the concise summaries, which are clearly set apart as text boxes, further help the reader to obtain a quick overview.

The authors' main arguments to support health and nutrition programmes are reiterated in several places and are summarized here: (i) disease affects education throughout childhood; (ii) improving children's health and nutrition brings substantial benefits for education; (iii) improving health and nutrition brings greatest benefits to the poor and most vulnerable; and (iv) health and education reinforce one another.

Their underlying rationale is that diseases that affect education are highly prevalent. Infants, pre-school and schoolchildren face many health challenges, such as pneumonia, malaria, measles, micro- and macronutrient deficiencies. Because these young children frequently suffer one or several of these problems concurrently, health and nutritional programmes focusing on this age group are extremely valid. Many of these diseases and deficiencies are preventable and, among the schoolchildren who bear the greatest burden, the most vulnerable ones are the poor.
The authors present the aggregated evidence of the various ways in which poor health and nutrition can affect children's access to education, such as delaying enrolment, increasing absenteeism and precipitating drop-out. They argue that school-based programmes are particularly good examples of effective interventions that tackle education and health at the same time. But it's not only during this phase that young children will benefit, good nutrition in pregnancy and infancy benefits health throughout the lifecycle.

Developing this idea further, the authors consider the effects of health and nutrition on behaviour and cognitive function. They present supporting evidence to show that a critical period for the educational benefits of good nutrition does not exist. Hence interventions must not just focus on a narrow age group: health and nutrition programmes are effective in improving education throughout life - even if the childhood period is the most effective one for many reasons. For example, a sick child who receives insufficient or nutrient-poor food will score lower in his or her educational achievement. Given that many schoolchildren suffer from nutritional deficiencies and infectious diseases, multiple micronutrient supplementation could be a promising school health and nutrition intervention.

Above all, such interventions are highly cost-effective when delivered via the school system rather than the health system. To support this argument, the authors present ways to calculate the cost-effectiveness of school health and nutrition programmes as a means of improving children's education. In their view, these estimates are conservative given that they measure only short-term impact while there certainly is also a long-term impact that has yet to be monitored and evaluated.

Tackling diseases of poor health and nutrition will not only have an immediate effect on an individual's education, by reducing the number of years of schooling that are lost to poor health, but school health and nutrition interventions can have an impact on education on a global scale.
In addition, school health and nutrition has the potential to improve equity in education by helping girls and children from low-income families to attain good (or at least some) education. The latter are likely to benefit more than their peers and so this will contribute to closing the knowledge gap between children from high and low socioeconomic groups, leading to more equitable job opportunities in later life.

The authors conclude with a list of key issues that should be taken into consideration when designing school health and nutrition programmes. Readers with any doubts will be convinced after reading this book that the issues of health, nutrition and school education are best tackled with a comprehensive approach. It is a sound foundation to argue the case for health, nutrition and education for all.

\section{Monika Blössner ${ }^{\mathrm{a}}$}

\section{Brock Chisholm, the World Health Organization, and the Cold War}

\section{Author: John Farley}

Publisher: University of British Columbia Press, Vancouver, 2008

ISBN: 978-0-7748-1476-8; hardback;

254 pages; US\$ 85

On the occasion of WHO's 60th anniversary, Brock Chisholm, the World Health Organization, and the Cold War is a story of the institution's formative years and its first Director-General.

The book is a detailed study by medical historian, John Farley, who has sifted through voluminous documentation to elucidate the complex relationships between a new postwar sociopolitical organization, an idealistic leader and a cruel Cold War atmosphere. The account is neither a full biography of Brock Chisholm nor a complete study of WHO but, as the introduction states, the "story" of both during their respective first steps in a hostile world.

Farley records Chisholm's qualities, from his youth as a brave soldier

a World Health Organization, 20 avenue Appia, 1211 Geneva 27, Switzerland.

Correspondence to Monika Blössner (e-mail: bloessnerm@who.int). 
to his growth as physician, psychiatrist, platoon commander, major-general, deputy minister of health, representative to the International Health Conference and, thence, to WHO. He notes that "Chisholm had been a surprising choice" yet, in the plethora of carefully referenced documents, there is no single statement or feeling supporting such a "surprise". Even if initially, in 1946, Chisholm might have been sent to the United Nations (UN) by virtue of his position in Canada's health administration, once in the international circuit, he constantly climbed with the votes of his peers, all experts such as Evang, Parran, Sand, Stampar and other Indian or Soviet influential figures. Such steady ascent from the Technical Preparatory Committee to the Interim Commission and up to the World Health Assembly cannot be a surprise or accident, especially as Chisholm never lobbied or asked for favours. Obviously he must have demonstrated superior mental, organizational and human qualities to have been repeatedly chosen as secretary, rapporteur, chairman and ultimately director-general. Dr Norman HowardJones, the historian of $\mathrm{WHO}$, is categorical about this: "he was the natural choice".

The Cold War is not particular to Chisholm's leadership of WHO; four of his successors having faced similar difficulties, machinations and injustices in that period. But it was he who was the first to confront it and, given the incredible and maddening political complexities due to east-west animosity, it is all to the credit of the "first captain" that damage control remained effective and the "ship" maintained its course. Farley fully documents the nasty politicking of those years but, despite extensive bibliographic material, a true interpretation of the leader's strong image does not emerge. Indeed, whether through concern for neutrality or objectivity, the author appears undecided, by using such ambiguous terms as visionary (repeated at least six times), nationalism and citizenship, which are open to ambivalent interpretations. This sometimes works against Farley, unwittingly portraying his subject in a lesser light; "visionary", for example, becomes almost derogatory, showing Chisholm as a vague, impractical dreamer. Strong views on such issues as family planning, poverty reduction, social services, medical coverage and peace-keeping come out as dreamy and indeed may have sounded outlandish in those hot years of the Cold War yet, with time, most have proven to be right.

Organizationally WHO, even in those earliest years, suffered from its Member States' nationalistic interests and lack of commitment yet Chisholm's team led bravely and reasonably successfully. His public health experience has sometimes been questioned. Farley addresses this issue but draws no conclusion. Although Chisholm was not from a Ministry of Public Health, he was surrounded by public health giants like Stampar and Evang and, as his objective was the public's health rather than traditional public health, being outside the club should be seen as an advantage, as indeed it proved to be. Naturally, like any other person, Chisholm had his "pet" topics and weaknesses but he knew how to deal with colleagues, opponents and difficult situations. He chose his team well and had confidence in youth: his directors of finance (Siegel) and of publications (Howard-Jones) were both aged 38 when appointed. I recall, when he officiated at our medical graduation, his passionate message was: "safeguard your youthful vision and work health into social justice".

This book is an excellent study. Intentionally limited in time and scope, it leaves some issues in suspense. A postscript could perhaps have mentioned that those early visionary ideas have turned out to be not that illusory after all. Chisholm's hope of universal health services now guides WHO's Global Strategy for Health for All; his advocacy of a peacekeeping force is now reality, albeit weak, through the UN Blue Berets; his ideas on world federalism are partly translated in the European Union; his anti-nuclear stand has seen the Pugwash Conferences on Science and World Affairs receive the Nobel Peace Prize; and his poverty-disease link is key to UN Millennium Development Goals. Social medicine has become widely available and family planning has hugely contributed to China and India's progress; the American Medical Association and the Catholic Church had once "crucified" Chisholm for such heresy. Farley's book clarifies much and should be read by medical historians, health planners, social scientists, politologues and international administrators.

\section{S William A Gunn ${ }^{\mathrm{a}}$}

\footnotetext{
a International Association for Humanitarian Medicine, 3 Chemin du Milieu, 1279 Bogis-Bossey, Switzerland.

Correspondence to S William A Gunn (e-mail: swagunn@bluewin.ch).
} 